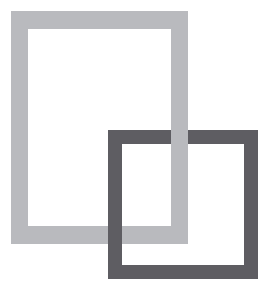

\title{
PONTISEUM - ZBIÓR EKSPONATÓW HISTORYCZNYCH, BĘDĄCYCH POZA KLASYFIKACJĄ ZABYTKÓW
}

\section{Pontiseum - a collection of historical exhibits that are outside} the classification of monuments

\section{Rymsza Barbara*, Mistewicz Anna**}

SUMMARY: Pontiseum, a place where pieces of the oldest bridges ever built in Warsaw are exhibited, was open in 2014 at the Road and Bridge Research Institute. This article describes how documents pertaining to proper classification of bridge remains and determining their status and establishment of ownership rights circulate between administrative bodies. Since bridge remains have not been classified as historic monuments, parties of proceedings interpreted them in different ways. Moreover, the article also explains the rules governing inclusion of similar items considered as historic monuments under different categories. The authors emphasize that it is of utmost importance to preserve them for future generations.

KEY WORDS: Pontiseum, bridges, protection, preservation, monuments of technology.

\section{Wprowadzenie}

Technika od zawsze była ważnym elementem naszej kultury, cywilizacji. Kolejne zdobycze techniki były bodźcem do rozwoju miast i ich infrastruktury. To nasza spuścizna intelektualna po przodkach, dorobek wielu pokoleń, którego częścią są również mosty.

W 2014 r. na terenie Instytutu Badawczego Dróg i Mostów w Warszawie (IBDiM) zostało uroczyście otwarte pierwsze na świecie PONTISEUM. Jego nazwę utworzono od włoskiego słowa ponti czyli mosty, analogicznie do słowa muzeum, które jest miejscem poświęconym muzom. PONTISEUM to miejsce poświęcone mostom (ryc. 1), których duże gabaryty uniemożliwiają utworzenie „klasycznego muzeum" mostów, stąd są eksponowane jak pomniki na wolnym powietrzu.

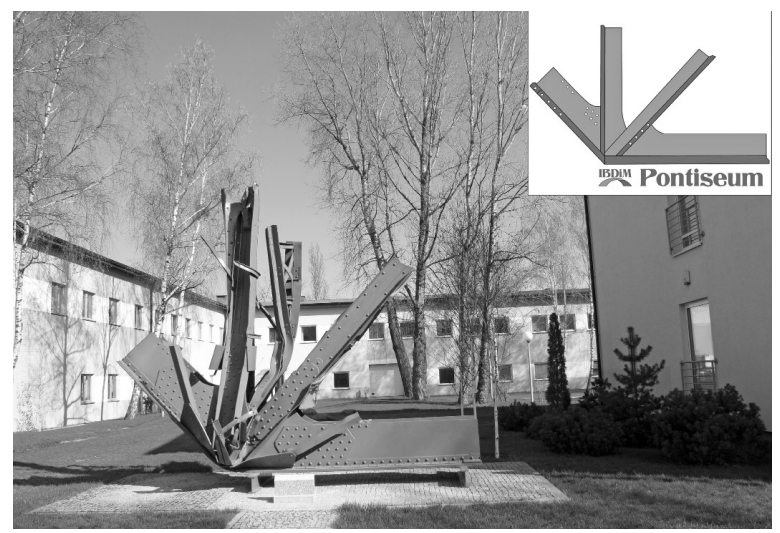

Ryc. 1 Fragment Mostu kolejowego pod Cytadelą na terenie IBDiM oraz logo Pontiseum (fot. B. Rymsza)

* $\quad$ PhD Arch. Barbara Rymsza, Research Institute of Roads and Bridges in Warsaw

https://orcid.org/0000-0002-0504-2360

Anna Mistewicz, National Museum in Warsaw

https://orcid.org/0000-0002-4216-1799 
W PONTISEUM IBDiM jest tworzona nowa historia starych konstrukcji mostowych ${ }^{1}$. W wypadku Warszawy mosty zostały wysadzone w powietrze podczas Powstania Warszawskiego, a ich fragmenty spoczywały blisko 70 lat na dnie Wisły.

Niniejszy artykuł jest poświęcony problemom, związanym z klasyfikowaniem elementów konstrukcji mostowych, których utrwaleniu służy PONTISEUM. Artykuł jest także swoistą historią zabiegów, związanych z przekazywaniem nietypowych eksponatów do muzeów.

\section{Historia wydobycia fragmentów konstrukcji mostowych}

W 2008 r. w trakcie prowadzonych prac czyszczenia toru wodnego Wisły zostały wydobyte z dna rzeki fragmenty nitowanej konstrukcji stalowej. Przed przekazaniem jej jako złom do przetopienia, grupa specjalistów z zakresu historii techniki mostownictwa wytypowała fragment konstrukcji, który przeznaczono do zachowania i do przeprowadzenia badań. W dniu 20 grudnia 2008 r. na terenie IBDiM został ustawiony, podniesiony z dna Wisły element Mostu pod Cytadelą (ryc. 1), dzięki któremu w Instytucie utworzono program badawczy pt. „Identyfikacja rozwiązań materiałowokonstrukcyjnych historycznych mostów stalowych w Warszawie”, mający na celu odszukanie i wydobycie „okruchów” konstrukcji najstarszych stałych mostów warszawskich².

Prace poszukiwawcze musiały być poprzedzone uzyskaniem stosownych pozwoleń. Znaczenie miała zarówno opinia Konserwatora, jak i Zarządcy Wisły, którą tutaj pominiemy, koncentrując się na temacie klasyfikacji i kategoryzacji zabytków.

Biuro Stołecznego Konserwatora Zabytków w piśmie z 14 kwietnia 2009 r. poinformowało, że „kawałki elementów konstrukcyjnych mostu, nie są obiektem zabytkowym i nie podlegają ochronie” oraz, że „zamierza zlecić wykonanie inwentaryzacji i dokumentacji fotograficznej wydobytych elementów mostów".

W styczniu 2013 r. Prezydent Miasta Stołecznego Warszawy wydaje decyzję, podpisaną przez Stołecznego Konserwatora Zabytków, w której orzeka „pozwolić Instytutowi Badawczemu Dróg i Mostów na przeprowadzenie poszukiwań i wydobycia wybranych fragmentów konstrukcji zniszczonych mostów na terenie rzeki Wisły (...)”.

Podobnie jak we wcześniejszych pismach Konserwatora, tak i w tym piśmie nie ma mowy o zabytkach, czy o zabytkowych mostach.

1 B. Rymsza, Pierwsze na świecie Pontiseum - adaptacja historycznych fragmentów konstrukcji mostowych do celów dydaktycznych, w: B. Szmygin (red.), Ochrona wartości w procesie adaptacji zabytków, PKN ICOMOS, Muzeum Pałacu Króla Jana III w Wilanowie, Politechnika Lubelska, Warszawa 2015, s. 241-246.

2 B. Rymsza, Na ratunek historycznym mostom Warszawy, Polskie Drogi no. 2/2012, s. 72-73. 


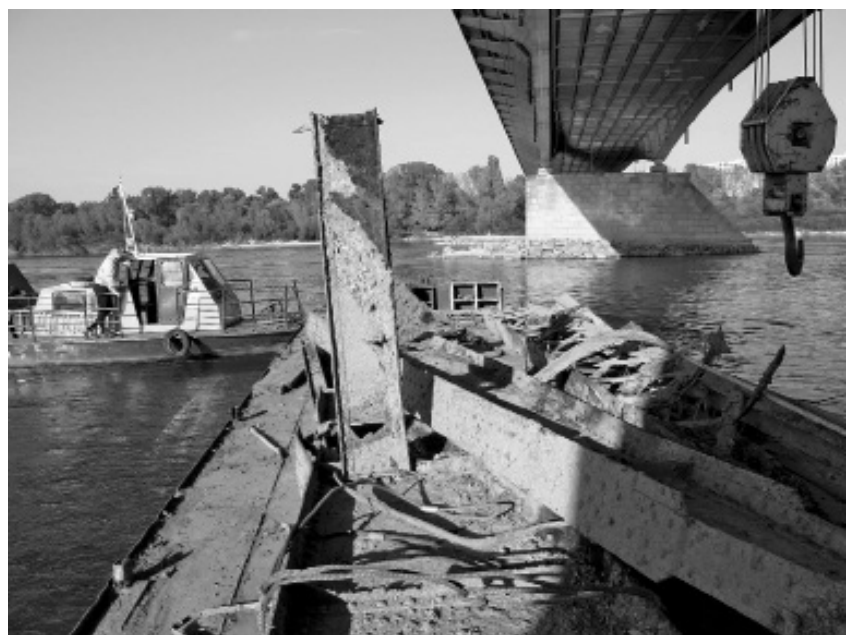

Ryc. 2 Prace poszukiwawcze fragmentów historycznych mostów Warszawy (fot. B. Rymsza)

Trwające prace poszukiwawcze historycznych mostów Warszawy (ryc. 2) wzbudzają ogromne, bardzo życzliwe zainteresowanie wśród Warszawiaków, ale także głosy negatywnie zaniepokojone. Między innymi Minister Kultury i Dziedzictwa Narodowego (w lipcu 2012 r.) wyjaśnia Komitetowi Upamiętnienia Ofiar Obozu Zagłady Konzentrationslager Warschau, że odnalezione "resztki przedwojennej konstrukcji Mostu Poniatowskiego to nie jest 'ostatnia już w Warszawie ruina pozostała w wyniku napaści Niemiec hitlerowskich na Polskę w 1939 r., jak to określa Komitet”.

\section{Plany utworzenia stałej ekspozycji mostowej w Warszawie}

Wydobyte fragmenty najstarszych stałych mostów w Warszawie powinny być utrwalone dla przyszłych pokoleń. Chociaż nikt nie nazywa tych „okruchów historii” zabytkami, to jest pełna zgoda na to, by je zachować (ryc. 3).

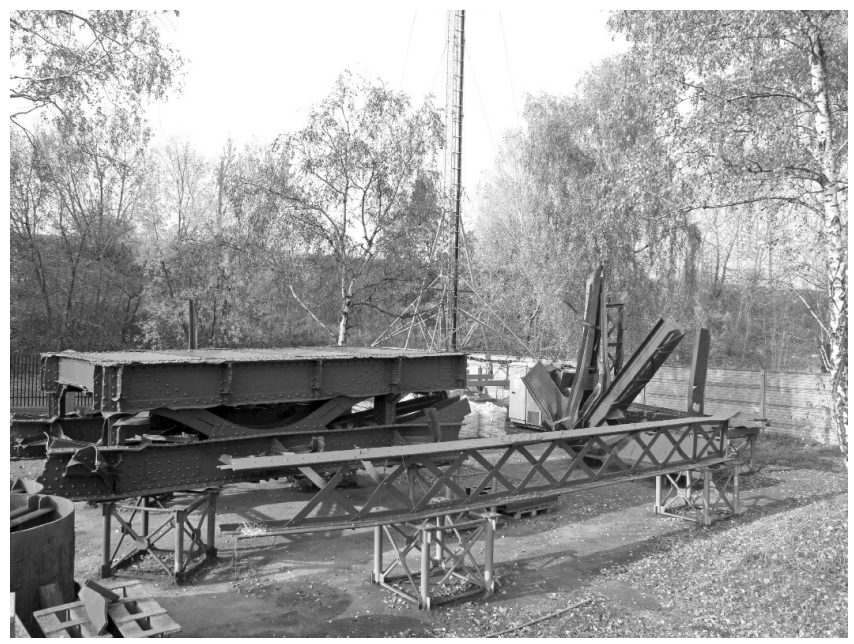

Ryc. 3 Wydobyte fragmenty warszawskich mostów po zabezpieczeniu antykorozyjnym (fot. B. Rymsza) 
W roku 2012 rodzi się porozumienie „W sprawie utworzenia stałej ekspozycji wydobytych z koryta rzeki Wisły historycznych mostów warszawskich” między Miastem Stołecznym Warszawa, w imieniu którego działa Zarząd Mienia m.st. Warszawy, a Instytutem Badawczym Dróg i Mostów, które mimo wielomiesięcznego dopracowywania warunków utworzenia ekspozycji nie zostaje zawarte.

Główny problem, to zdefiniowanie, na jakiej podstawie Miasto Stołeczne Warszawa przejmuje wydobyte elementy konstrukcji i na jakich warunkach Instytut może te elementy miastu przekazać.

Co więcej, w tym samym czasie opracowano projekt inwestycji „Zagospodarowanie lewobrzeżnego Bulwaru Wisły” na odcinku od ul. Tamka do ul. Boleść, uwzględniający lokalizację stałej ekspozycji mostowej. I choć w planach były i porozumienie i ekspozycja, do dzisiaj miasto Warszawa ich nie ma. Zorganizowano natomiast kilka wystaw z udziałem eksponatów wypożyczonych z Instytutu.

W listopadzie 2013 r. została otwarta w Muzeum Politechniki Warszawskiej wystawa poświęcona inżynierowi J. A. Majewskiemu, który uczestniczył w budowie Mostu Kierbedzia i Mostu im. Ks. Józefa Poniatowskiego ${ }^{3}$. Fragment balustrady z tego ostatniego znalazł się wśród wystawianych eksponatów.

W roku 2014 wystawę „Dwa mosty Warszawy” z okazji 150-lecia Mostu Kierbedzia i 100-lecia Mostu Poniatowskiego przygotowano pod patronatem Biura Stołecznego Konserwatora Zabytków w Warszawie ${ }^{4}$. Przedstawiono historię mostów na pięknie skomponowanych planszach, ale zaprezentowano także fragmenty konstrukcji mostów wydobyte z Wisły. To głównie owe „okruchy” przyciągały uwagę przechodniów i czyniły z nich widzów. Jednym z eksponowanych elementów był fragment balustrady z Mostu im. Ks. Józefa Poniatowskiego.

\section{Najnowsza historia fragmentów balustrady z mostu im. Ks. Józefa Poniatowskiego}

Prezentowana balustrada zachwyciła także innych muzealników. Dwa muzea zwróciły się do IBDiM z prośbą o fragment balustrady mostu znanego z historii przewrotu majowego w roku 1926, kiedy marszałek Józef Piłsudski spotkał się na moście Poniatowskiego z prezydentem RP Stanisławem Wojciechowskim (ryc. 4).

3 A. Mistewicz, Z. Tucholski, "Inżynier Julian Adam Majewski. Historia pierwszych stałych mostów Warszawy" - wystawa w Muzeum Politechniki Warszawskiej, Kronika Warszawy nr 2 (149) 2013, s. 170-174.

4 A. Mistewicz, Z. Tucholski, B. Rymsza, J. Rymsza, Dwa Mosty Warszawy. 150 lat Mostu Kierbedzia i 100 lat Mostu Poniatowskiego, Two Bridges of Warsaw. 150 Years of Kierbedź Bridge \& 100 Years of Poniatowski Bridge, Miasto Stołeczne Warszawa, Warszawa 2014. J. S. Majewski, T. Urzykowski, Pontiseum na urodziny warszawskich mostów, http://m.warszawa.gazeta.pl/warszawa/1,106541,16218352,Pokazali_czesci_dwoch_mostow_ wydobyte_z_Wisly__Bedzie.html, dostęp 16.02.2015. 


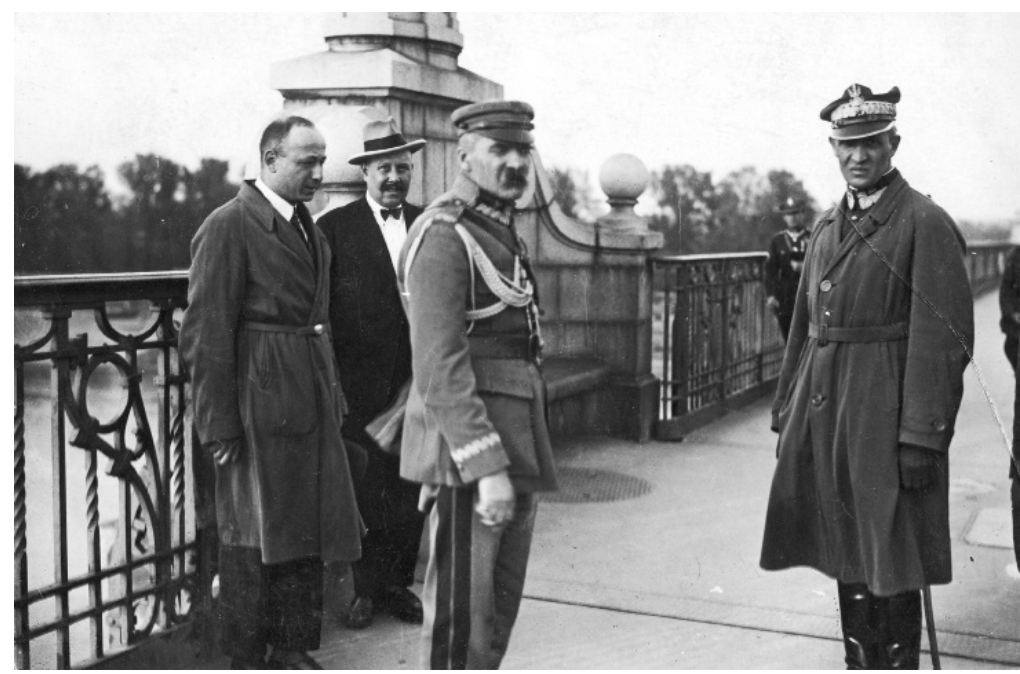

Ryc. 4 Marszałek Józef Piłsudski na Moście im. Ks. Józefa Poniatowskiego tuż przed spotkaniem z prezydentem RP Stanisławem Wojciechowskim, 12 maja 1926 r. (źródło: zbiory Muzeum Józefa Piłsudskiego w Sulejówku)

Niestety przekazanie fragmentów balustrad do muzeów okazało się nie być łatwe, za sprawą pytań: jak należy zakwalifikować elementy wydobyte $\mathrm{z}$ Wisły i jaka jest podstawa prawna do dysponowania nimi. Problem ważny, bo powracający zarówno w sytuacji chęci przekazania niewielkich fragmentów balustrady, ale także w kontekście utworzenia PONTISEUM w centrum miasta.

Należało zatem uzyskać odpowiedź na wyżej postawione pytania. Przekazano je do Biura Stołecznego Konserwatora Zabytków (lipiec 2015 r.), z prośbą o potwierdzenie możliwości dysponowania fragmentami konstrukcji mostów wydobytych z Wisły, a przeznaczonych do badań albo do eksponowania w PONTISEUM lub na wystawach. Stołeczny Konserwator Zabytków stwierdził, że nie dostrzega przeszkód konserwatorskich w dysponowaniu przez IBDiM fragmentami konstrukcji, natomiast przekazał pismo (wrzesień 2015 r.) do Zarządu Mienia Skarbu Państwa, dalej pismo z Zarządu z pytaniami w sprawie trafiło do Biura Gospodarki Nieruchomościami Wydziału Gospodarki Nieruchomościami Skarbu Państwa Urzędu m. st. Warszawy (październik 2015 r.).

Kolejne pismo, z Biura Gospodarki Nieruchomościami, zostało wysłane pod koniec października 2015 r. do Wydziału Skarbu Państwa i Nieruchomości Mazowieckiego Urzędu Wojewódzkiego. W piśmie tym obok informacji o wojennych losach mostów i o pracach prowadzonych przez IBDiM, przywołano także opinię Stołecznego Konserwatora Zabytków, który „uznał, że fragmenty konstrukcji mostów nie są obiektami zabytkowymi i nie podlegają ochronie". Ważne wydawało się także stwierdzenie, że „W wyniku zburzenia konstrukcji mostu, odnaleziona konstrukcja przestała być częścią składową nieruchomości, (patrz Komentarz do art. 47 Kodeksu Cywilnego autorstwa Wojciecha Jana Katnera, opublikowany LEX 2014 r.), w związku z czym w niniejszej sprawie nie ma zastosowania art.11 ustawy z dnia 21 sierpnia 1997 r. o gospodarce nieruchomościami (tj. Dz. U. z 2015 r., poz. 78 ze zm.)”.

30 listopada 2015 r. Mazowiecki Urząd Wojewódzki, Wydział Skarbu Państwa i Nieruchomości wystąpił z wnioskiem do Departamentu Skarbu Państwa Ministra Skarbu Państwa „o zajęcie stanowiska czy fragmenty wyżej wymienionych mostów wydobyte z Wisły mieszczą się w kategorii mienia przejętego przez Skarb Państwa z innych tytułów, zgodnie z art. 7b ust. 1 pkt 1 lit c ustawy z dnia 08 sierpnia $1996 \mathrm{r}$. 
o zasadach wykonywania uprawnień przysługujących Skarbowi Państwa (Dz.U. z 2012r. poz. 1224), którym gospodaruje wojewoda mazowiecki. Jeżeli tak, to zwracam się z uprzejmą prośbą o wyrażenie zgody na przekazanie wyżej wymienionych konstrukcji mostów na rzecz Instytutu Badawczego Dróg i Mostów Warszawie."

23 grudnia 2015 r. Mazowiecki Urząd Wojewódzki w Warszawie, Wydział Skarbu Państwa i Nieruchomości, zwrócił się do Instytutu Badawczego Dróg i Mostów z pytaniem „kto był właścicielem tych mostów”, bowiem z takim pytaniem zwrócił się do Mazowieckiego Urzędu Wojewódzkiego Departament Skarbu Państwa Ministra Skarbu Państwa, celem ustalenia organu właściwego do gospodarowania tym mieniem.

Departament Mienia Skarbu Państwa w Ministerstwie Skarbu Państwa podsumował, bo nie zakończył, wędrówkę pism ustalających zasady i formę zakwalifikowania fragmentów konstrukcji mostowych pismem z dnia 5 stycznie 2016 r. Znajdujemy w nim taką informację „Departament Mienia Skarbu Państwa zajmie stanowisko w sprawie po jednoznacznym ustaleniu stanu faktycznego i prawnego, w tym zakresie, kto był właścicielem mostów, kto jest obecnie właścicielem znalezionych fragmentów pozostałych po zniszczonych mostach i na jakiej podstawie (...)".

W taki sposób, zaczął się kolejny rok, a pytanie w zmienionej formie wróciło do Instytutu. Tymczasem fragmenty balustrad czekają, tak jak czekają i fragmenty pozostałych mostów.

W wypadku balustrad wybrnięto z tej nierozwiązanej przez kilka lat sytuacji, braku decyzji odnośnie do kwalifikacji fragmentów konstrukcji mostowych, podpisując umowy, w których balustrady określono mianem „przedmiotu objętego umową” i przyjęto nieodpłatne, „tymczasowe przekazanie w depozyt fragmentu balustrady pochodzącej z przedwojennego Mostu Poniatowskiego, na czas do ustalenia warunków formalnych dysponowania fragmentami konstrukcji mostowych wydobytych z Wisły przez IBDiM”.

\section{Znaczenie wydobytych fragmentów konstrukcji i próba ich skategoryzowania}

Część wydobytych z dna Wisły fragmentów mostów, ze względu na nieudane próby pozyskania funduszy na ich badania i konserwację (wnioski do Ministra Nauki i Szkolnictwa Wyższego, Narodowego Centrum Nauki), została zabezpieczona antykorozyjnie sposobem gospodarczym w Instytucie Badawczym Dróg i Mostów i wyeksponowana w Pontiseum (ryc. 5).

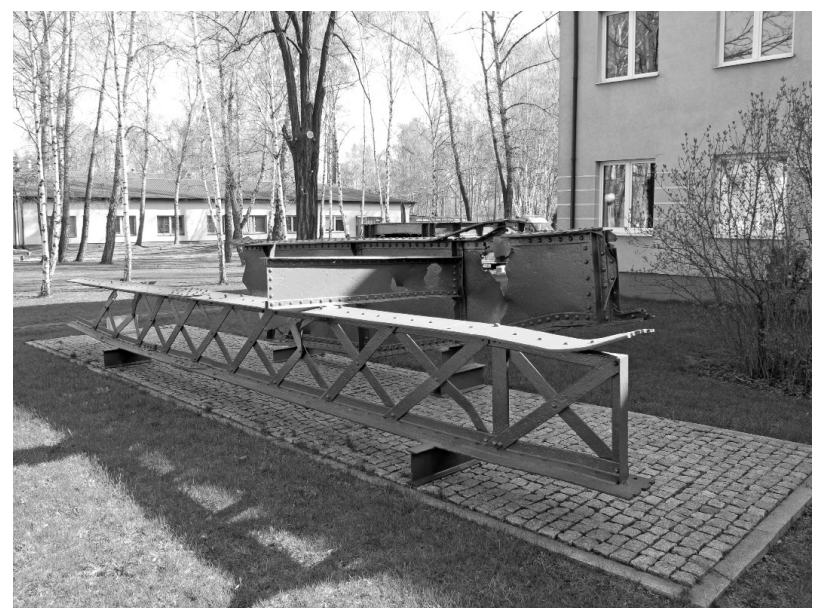

Ryc. 5 Fragmenty Mostu Kierbedzia eksponowane na terenie IBDiM (fot. B. Rymsza) 
Pozostałe fragmenty wciąż czekają na konserwację i decyzję odnośnie do ich ewentualnego wyeksponowania nad Wisłą. Fragmenty mostów prezentowane w Pontiseum to pozostałości najstarszych stałych mostów warszawskich: Mostu Kierbedzia (1859-1864), mostu kolejowo-drogowego pod Cytadelą (1873-1875), mostu kolejowego pod Cytadelą (1905-1908), oraz Mostu im. Ks. Józefa Poniatowskiego (19041914). Fragmenty Mostu Kierbedzia mogą być już ostatnimi pozostałościami konstrukcji z 2 połowy XIX w. - w trakcie przeszukiwań dna Wisły sonarem nie zarejestrowano żadnych innych sygnałów.

Te resztki budowli są świadectwami rozwoju techniki i mostownictwa w Polsce. Wszystkie wymienione mosty były konstrukcjami stalowymi, nitowanymi. Nitowanie jest techniką już sporadycznie stosowaną w budownictwie mostowym. W ciągu najbliższych lat ostatnie, jeszcze eksploatowane, tego typu konstrukcje mogą być, ze względu na brak ochrony konserwatora i ich wiek, stopniowo zastępowane nowszymi konstrukcjami.

Mosty te wielokrotnie były świadkami ważnych wydarzeń z dziejów Warszawy i Polski. Są to też miejsca upamiętniające wydarzenia historyczne. Niektóre z wydobytych fragmentów noszą ślady uszkodzeń, są zdeformowane, rozdarte w wyniku eksplozji materiałów wybuchowych w 1944 r. (ryc. 1).

Z ogromnym trudem odszukane i wydobyte fragmenty mostów warszawskich zasługują na zachowanie dla przyszłych pokoleń. Pod względem merytorycznym, prawnym, naukowym celowe jest ich zaliczenie w poczet zabytków. Wpisują się w definicję zabytku według Ustawy o ochronie zabytków i opiece nad zabytkami ${ }^{5}$.

W wykazie obiektów wpisanych do rejestru zabytków są wymienione mosty i wiadukty będące w użyciu: np. odbudowany most i wiadukt im. Poniatowskiego w Warszawie z poł. XX w., $\mathrm{nr}$ rej. 748 z 1.07.1965, wiadukt im. Markiewicza przy ul. Karowej, z pocz. XX w., nr rej. 681 z 1.07.1965, mostek przy ul. Wiertniczej 1, z 1 poł. XIX w., nr rej. 639/33 z 2.1973, oraz fragmenty mostów już zamkniętych dla ruchu kołowego jak 3 przęsła mostu drogowego w Tczewie, z lat 1851-1857, nr rej. A-1210 z 21.03.2000. Są także użytkowane mosty, będące częścią większych założeń, np. most z pocz. XIX w. w zespole pałacowym "Królikarnia" ul. Puławska 113, nr rej. 456/2 z 1965 r. czy most z pomnikiem króla Jana III z 1783 r., w Łazienkach Królewskich, nr rej. 1 z 1.07.1965․ Wszystkie, jako elementy budownictwa przemysłowego, zaliczyć można do grupy obiektów techniki. W rejestrze zabytków znajdują się też m. in.: ogrodzenia, bramy i kordegardy, pomniki, fontanny i studnie, czy mała architektura parkowa, które zaszeregowane są do kategorii INNE. Zbliżone typy obiektów, „których 'ruchomość' jest problematyczna”, są wpisywane również do wykazu zabytków tzw. ruchomych, ale wówczas „...muszą w pełni posiadać charakter indywidualnych, niepowtarzalnych tworów artystycznych"7.

Pozostaje pytanie, jak należałoby zakwalifikować fragmenty mostów? W 1948 r. Tadeusz Kantor zapisał w swoim notatniku: „Zaraz po wojnie w Warszawie zobaczyłem kawałek żelaznego mostu rozbitego bombą. Gdyby ktoś ustawił ten obiekt na Placu Unii jako rzeźbę, w przyszłości historycy odczytaliby w splotach jego formy - siły rządzące naszą epoką." Czym są więc prezentowane obiekty - pomnikami

5 „Zabytek - nieruchomość lub rzecz ruchoma, ich części lub zespoły, będące dziełem człowieka lub zwiąane z jego działalnością i stanowiące świadectwo minionej epoki bądźz zdarzenia, których zachowanie leży winteresie społecznym ze względu na posiadana wartość historyczną, artystyczną lub naukową" (Ustawa z dnia 23 lipca 2003 r. o ochronie zabytków i opiece nad zabytkami art. 3, pkt.1).

6 http://www.nid.pl/pl/Informacje_ogolne/Zabytki_w_Polsce/rejestr-zabytkow/zestawienia-zabytkow-nieruchomych/; dostęp 17.04.2016.

7 http://www.nid.pl/pl/Informacje_ogolne/Zabytki_w_Polsce/rejestr-zabytkow/zestawienia-zabytkow-ruchomych/; dostęp 17.04.2016.

8 W. Borowski, Tadeusz Kantor, Wydawnictwa Artystyczne i Filmowe, Warszawa 1982, s. 161. 
techniki o znaczeniu edukacyjnym, fragmentami konstrukcji, zachowanymi jako materiał naukowy, czy powinny być one może, ze względu na okoliczności ich wydobycia, traktowane jak znaleziska archeologiczne?

\section{Wnioski}

Przy tworzeniu kategoryzacji zabytków należy uwzględnić nietypowe obiekty - wyróżnić osobną kategorię obiektów skromnych, jak to zostało określone w Karcie Weneckiej z 1964 r.9 w tym przypadku świadectw rozwoju techniki, inaczej często tego typu obiekty nie będą w ogóle klasyfikowane jako zabytkowe.

Być może dobrym pomysłem są stosowane w krajach anglosaskich tematyczne przeglądy obiektów pod kątem konkretnej kategorii obiektu lub tematyki ${ }^{10}$, mające na celu wyodrębnienie najcenniejszych, najlepszych przykładów danego typu zabytku, w celu ich zachowania dla przyszłych pokoleń. Podkreślić należy konieczność posiadania przez osoby przeprowadzające takie tematyczne przeglądy odpowiedniej wiedzy, również na temat historii poszczególnych miejsc, objętych badaniem, dotyczącą ważnych wydarzeń, które miały w nich miejsce. Jednym z istotnych elementów ochrony zabytków w Wielkiej Brytanii jest obecnie infrastruktura.

„Zasadniczo uważa się wszystkie zabytki za równie cenne”11. Ustawa o ochronie zabytków art. 6, ust. 1 mówi, że ochronie i opiece podlegają zabytki „bez względu na stan zachowania”. Wskazane byłoby jednak uwzględnienie przy klasyfikacji zabytków skali stanu zachowania obiektów objętych ochroną. Niektóre obiekty mogą przestać istnieć w ciągu kilku, kilkunastu lat - klasyfikacja powinna pomóc je wyodrębnić, niezależnie od tego, do której klasy pod względem wartości należałoby je zaliczyć. Takie klasyfikacje ze względu na stan zachowania funkcjonują z powodzeniem odnośnie do zabytków muzealnych, w wielu muzeach na całym świecie i w Polsce.

Niektóre mosty są osiągnięciami techniki na skalę europejską lub nawet światową. Powinniśmy dołożyć wszelkich starań, aby zachować je, lub przynajmniej ich fragmenty, dla przyszłych pokoleń.

9 „DEFINICJE Art. 1. Pojęcie zabytku obejmuje zarówno odosobnione dzieło architektoniczne, jak też zespoły miejskie i wiejskie oraz miejsca, będące świadectwem poszczególnych cywilizacji, ewolucji o doniostym znaczeniu bądź wydarzenia historycznego. Rozciąga się ono nie tylko na wielkie dzieła, ale również na skromne obiekty, które z uplywem czasu nabrały znaczenia kulturalnego., http://www.ochrona.zabytki.lodz.pl/data/ other/karta_wenecka.pdf; dostęp 16.04.2016.

10 np. przegląd zabytkowych pomp czy przegląd pubów z okresu międzywojennego czy miejsc związanych z I Wojną Światową; https://www.doeni.gov.uk/articles/historic-buildings-surveys; dostęp 17.04.2016. https:// historicengland.org.uk/listing/apply-for-listing/listing-priorities/; dostęp 17.04.2016.

11 https://pl.wikipedia.org/wiki/Zabytek; dostęp 16.04.2016 